\title{
Preparing for Adulthood: A Recent Examination of the Alignment of Rural Youth's Future Educational and Vocational Aspirations
}

\author{
Judith L. Meece ${ }^{1}$, Bryan C. Hutchins ${ }^{1}$, Soo-yong Byun ${ }^{2}$, Farmer, T. W. ${ }^{3}$, Matthew J. Irvin ${ }^{4} \&$ Margaret Weiss ${ }^{1}$ \\ ${ }^{1}$ School of Education, University of North Carolina-CH, Chapel Hill, NC, USA \\ ${ }^{2}$ College of Education, Pennsylvania State University, University Park, PA, USA \\ ${ }^{3}$ School of Education, Virginia Commonwealth University, Richmond, VA, USA \\ ${ }^{4}$ College of Education, University of South Carolina, Columbia, SC, USA \\ Correspondence: Judith L. Meece, School of Education, CB\#3500, University of North Carolina-CH, Chapel \\ Hill, NC, USA. Tel: 1-919-929-2898. E-mail: meece@email.unc.edu
}

Received: November 26, 2012

Accepted: February 26, 2013

Online Published: October 18, 2013

doi:10.5539/jedp.v3n2p175

URL: http://dx.doi.org/10.5539/jedp.v3n2p175

\begin{abstract}
Nearly nine million students attend public schools in rural areas but limited research has examined the aspirations of rural youth in the early years of the 21st century. This study presents a contemporary profile of rural youth's educational and vocational aspirations and examines the educational alignment of reported aspirations. Using multinomial regression procedures, the study also examines the role of multiple contexts (family, individual, and school) in explaining variations in rural youth's aspirations. The results indicated a majority of rural youth wanted to obtain a two- or four-year college degree, and they aspired to adulthood occupations requiring college degrees. More than half of the sample reported misaligned educational and vocational aspirations and patterns of alignment were predicted by family income, student background, geographic isolation, and school-related experiences. The results highlight the need for additional research on high school programs to prepare rural youth for the transition to adulthood.
\end{abstract}

Keywords: rural youth, aspirations, schooling experiences, postsecondary education, vocational development

\section{Introduction}

Youth's aspirations are significant predictors of postsecondary educational attainment, occupational attainment, and successful early adulthood transitions (Bandura, Barbaranelli, Caprara, \& Pastoerelli, 2001). Although the transition to adulthood is often challenging for most youth (Eccles, Brown, \& Templeton, 2008; Zarrett \& Eccles, 2006), many rural communities, schools, and families have unique features and challenges that can constrain youth's postsecondary aspirations and attainment. These educational and occupational barriers include geographic isolation, few local postsecondary educational and occupational opportunities, a narrow school curriculum, and social and cultural expectations that do not support postsecondary education (Elder \& Conger, 2000; Farmer et al., 2006; Hardré, Sullivan, \& Crowson, 2009; Roscigno, Tomaskovic-Devey, \& Crowley, 2006). Over the last three decades, significant changes have occurred in rural communities (Brown \& Schafft, 2010; Carr \& Kefalas, 2009; Famer et al., 2006). Yet limited research has examined the contemporary aspirations of rural youth as they prepare for the transition adulthood.

Accordingly, using survey data on nearly 5000 rural youth, this study addressed the following questions: (1) What are the future educational and occupational aspirations of contemporary rural youth? (2) What contextual factors (family, individual, school) shape rural youth's educational and occupational aspirations? (3) Do rural youth hold educational goals that are appropriate for and aligned with their intended career path? (4) What contextual factors (family, individual, school) explain variations in the alignment of rural youth's educational and vocational goals?

\subsection{Aligned and Misaligned Ambitions}

The educational and vocational aspirations of youth are important to study. Psychological and sociological research has shown that youth's aspirations are significant predictors of educational and occupational attainment in early adulthood and beyond (Bandura et al., 2001; Beal \& Crockett, 2010; Schneider \& Stevenson, 1999). 
From a motivation perspective, aspirations serve as cognitive representations of a desired goal that organize, guide, and direct behavior (Bandura, 1986). Youth who leave high school with a sense of direction and purpose are likely, with appropriate economic and social supports, to make a successful transition and adaptation to early adulthood (Eccles et al., 2008; Elder \& Conger, 2000). Among youth in the United States, postsecondary educational aspirations have increased steadily over the past 30 years (Goyette, 2008; U.S. Department of Education, 2005). These trends also are found for rural youth. A recent report indicated that rural youth have experienced the greatest increase in college attendance compared to youth in suburban and urban areas (Synder \& Dillow, 2010).

Rather than examining youth's educational and vocational aspirations as separate entities, Schneider and Stevenson (1999) argued that it is important to examine their relationship. Youth with aligned ambitions report educational expectations that are consistent with their intended occupational goals. These youth are knowledgeable of the education needed for their future occupational goal, and they use available resources more strategically. In high school, for example, youth with aligned aspirations select courses, extracurricular activities, and social networks that enable them to achieve their goals (Schneider \& Stevenson, 1999). In contrast, youth with misaligned ambitions tend to underestimate or overestimate the level of education needed to achieve their goals. Recent evidence indicates that misaligned ambitions in adolescence may have long-term consequence $\mathrm{s}$ such prolonged schooling, low educational attainment, employment instability, and low adulthood earnings (Sabates, Harris, \& Staff, 2011).

Little is known about the alignment of educational and vocational goals of rural youth. As previously discussed, many rural youth face unique challenges as they prepare for the transition to adulthood. Extending the research of Schneider and Stevenson (1999), the current study examines whether the educational aspirations of rural youth are aligned with their vocational aspirations. The study draws on a large sample of rural youth from across the United States. The study also considers the relation of individual, family, and school characteristics to the alignment of rural youth's educational and occupational aspirations, with a special focus on adolescents' schooling experiences.

\subsection{Contextual Influences on Rural Youth's Future Aspirations}

To explore the alignment between rural high school students' educational and vocational aspirations, the current study was guided by developmental science which merges ecological and developmental systems perspectives to explain adaptation across the life course (Bronfenbrenner \& Evans, 2000; Cairns, Elder, \& Costello, 1996). From this perspective, youths' future goals are influenced not only by individual characteristics (e.g., ability, gender, race and ethnicity) but also family background, community resources, and school contexts. Several recent studies have applied an ecological or developmental systems framework to explain variations in educational and occupational attainment of rural youth (Crockett et al., 2000; Elder \& Conger, 2000; Demi, Coleman-Jensen, \& Synder, 2010).

\subsubsection{Characteristics of Rural Families in United States}

Numerous studies have consistently documented that U.S. youth from low-income families are less likely than more affluent youth to complete high school (Coleman, 1988; McNeal, 1999) and to attend college (Bozick \& Delucca 2005; Smith, Beaulieu, \& Seraphine, 1995). When compared to metropolitan youth, rural youth are often portrayed as disadvantaged due to the lower socioeconomic and occupational status of rural families (Cobb, McIntire, Pratt, 1989; Howley, 2006; Roscigno \& Crowley, 2001; Roscigno et al., 2006). Rural parents are also less likely than metropolitan parents to encourage high postsecondary attainment (Smith et al., 1995). These comparative studies of rural and urban youth have largely followed a rural disadvantaged model (Howley, 2006; Roscigno et al. 2006) and neglected other sources of support for youth development. Rural communities are high in social capital (Note 1) due to small size, shared values and norms, and connections between families, schools, and religious institutions (Crockett et al., 2000; Elder \& Conger, 2000). For rural youth, adult aspirations are related to their connections to family and community (Elder et al. 1996; Crockett et al., 2000; Johnson, Elder, \& Stern, 2005), and these relations, along with family resources, need to be considered.

\subsubsection{Individual Characteristics of Rural Youth}

Very limited research is available on the role personal attributes in shaping the adult aspirations of rural youth in the United States. Recent studies reveal that adolescent girls were more likely than adolescent boys to report higher educational and occupational aspirations (Chenoweth \& Galliher 2004; Elder \& Conger 2000). Because prior high school investigations were disproportionately composed of White students (e.g., High School and Beyond of 1980), few studies have examined the role of race and ethnicity in predicting adult aspirations among rural youth (Gándara, Gutierrez, \& O'Hara, 2001). 
Beyond social background variables, the residential preferences of rural youth also need to be considered. As suggested, rural youth's future goals are shaped by socioeconomic circumstances, attachment to community, and perceptions of local economic opportunities (Crockett et al., 2000; Elder \& Conger, 2000; Petrin et al., 2011). Given variations in economic opportunities within and across rural communities, residential preferences are particularly important for examining the adult aspirations and alignment of rural youth.

\subsubsection{School Characteristics and School Experiences}

Schools play an important role in preparing youth for the future. In the United States, rural schools are highly diverse but share several features that promote positive youth development, such as small size, strong parent involvement, and low rates of behavior problems (Provasnick et al., 2007). Students in smaller schools also benefit from close student-teacher relations (Hardré et al., 2009), stable peer relations (Estell, Farmer, Cairns, \& Cairns, 2002), and opportunities for greater involvement in school activities (Irvin, Farmer, Leung, Thompson, \& Hutchins, 2010). Generally, these school experiences promote school belonging, engagement, and achievement to positively shape rural youth's educational plans (Demi et al. 2010; Hardré \& Hennessey, 2010; Hardré et al., 2009). However, rural students also experience some limiting school features. Specifically, rural youth have a greater likelihood than their metropolitan counterparts to experience a narrow school curriculum, shortage of teachers with advanced degrees, and limited access to career counseling and college preparatory programs (Provasnik et al., 2007).

Whereas prior research has examined the role of individual and family characteristics in shaping the aspirations of rural youth, less is known about the role of schooling experiences in shaping the educational and occupational aspirations of rural youth. Rural schools are traditionally expected to provide youth with strong educational foundations to sustain rural culture, lifestyles, and economies (Brown \& Schafft 2010; Corbett 2007; Farmer et al., 2006). On the other hand, current educational mandates emphasizing national curriculum standards, standardized assessments, and college preparation may be preparing youth for a future very different from where they currently live (Corbett, 2007; Schafft, 2010). Rural youth often experience a tension between moving away to pursue educational and vocational opportunities not supported in their home communities, while remaining close to family and community (Corbett, 2007; Farmer et al., 2006; Hektner, 1995). Such conflicts can significantly influence youth's educational and vocational aspirations as well as lead to unrealistic expectations for the future.

\section{The Current Study}

Four specific research aims guided this study. The first aim was to provide a descriptive profile of the educational and vocational aspirations of U.S. rural youth in the early years of the 21 st century, after decades of economic decline in many rural communities. The second aim was to examine the role of multiple factors and contexts (family, individual, school, and community) in shaping youth's aspirations. The third aim was to examine the alignment of youth's educational and vocational aspirations. The final analyses examined predictors of alignment and misalignment. As stated earlier, misaligned ambitions can have serious long-term consequences for rural youth. An important goal of this study was to examine the role of school experiences in the formation of aligned and misaligned ambitions.

\section{Methods}

\subsection{Sample}

The current study was part of a broader investigation to examine students' school adjustment and postsecondary aspirations in rural high schools across the United States. Youth in Grades 9-12 were recruited from 73 schools in 34 states, with 89 percent of the schools from rural urban-centric locale codes $(41,42$, and 43$)$ and $11 \%$ from small-town codes $(31,32$, and 33). Sampling was based on a two-stage process whereby schools were first selected using U.S. Department of Education's Common Core of Data (CCD). The research designed placed a special emphasis schools receiving federal funding for the Rural Low Income Schools and the Small Rural School Achievement Program. (Note 2)

For the present investigation, we included only those students attending rural high schools (i.e., rural fringe, rural distant, and rural remote) and reporting educational as well as occupational aspirations. We excluded those students who answered "don't know" to the question asking about their educational and vocational aspirations (approximately 7 percent of the total rural sample). (Note 3) We also excluded Asian American students due to small sample sizes (less than $1 \%$ of the total rural sample). Student demographics for the final sample of 4,840 high school students (Grades 9 to 12 ) were as follows: $51 \%$ attended rural remote schools, $55 \%$ were female, 
$68 \%$ were white, $13 \%$ were multiracial, $8 \%$ were African American, $7 \%$ were Hispanic, and $4 \%$ were Native American.

\subsection{Data Collection Procedures}

Recruitment and consenting procedures followed the participating school districts' local policies and administrative guidelines. Data were collected during the 2007-2008 academic year at each school site and involved gathering information on students via separate student and teacher instruments. The student instrument consisted of a paper and pencil questionnaire administered on-site by a team of trained researchers. Student surveys were group-administered in a common space on the school campus (e.g., cafeteria, library, etc.).

\subsection{Variables (Note 4)}

\subsubsection{Dependent Variables}

For outcome measures, we used educational aspirations, occupational aspirations, and alignment between these two. Educational aspirations were based on students' answer to a question of "how far in school would you most like to go?" The response options given were: $1=$ less than high school graduation; $2=$ high school graduation or GED only; 3 = attend or complete a 2-year school course in a community college, vocational, or trade school; $4=$ attend college, but not complete a 4 -year degree; $5=$ graduate from college; $6=$ obtain a master's degree or equivalent; $7=$ obtain a Ph.D., M.D., or other advanced degree; and $8=$ don't know. These above response options were then collapsed into four groups with the exclusion of the "don't know" category: (a) less than high school or high school diploma, (b) some college, (c) four-year degree, and (d) advanced/professional degree. Occupational aspirations were based on the students' answer to this open-ended question: "What kind of job or occupation will you most like to have at age 30?" (Note 5)

To create the alignment variable, we coded each open-ended occupational response into an occupational category that then could be classified according to the level of education typically needed to perform the intended occupation. We used the Occupational Information Network $\left(\mathrm{O}^{*} \mathrm{NET}\right)$ to code vocational responses into five job zones, which represent the average level of training, experience, and education needed for each occupation (Note 6). Typical education requirements for each of the five job zones were: $1=$ less than high school diploma/GED; 2 = high school diploma; 3 = some college (e.g., vocational training, associate's degree); 4 $=$ four year bachelor's degree; and $5=$ advanced/professional degree. To be consistent with the categories of educational aspirations, we collapsed the five job zone categories into four groups: (a) less than high school or high school diploma; (b) some college; (c) four-year degree; and (d) advanced/professional degree. Next, we created an alignment score by subtracting the education level of the occupational aspiration category (zone categories $=1-5$ ) from the level of educational aspiration (response options $=1-8$ ) for each student. Using this procedure, each student was assigned an alignment score that ranged in value from -3 to +3 based on similar procedures used by Schneider and Stevenson (1999). Students who aspire to a level of education that is typically required to meet their occupational aspirations would receive a score of 0 and would be considered to have aligned ambitions. Students with positive scores were classified as over-aligned. Those students with negative scores were classified as under-aligned. This procedure resulted in five alignment groups: -3 to $-2=$ under-aligned; -1 slightly under-aligned; $0=$ aligned, 1 = slightly over-aligned; 2 to $3=$ over-aligned.

\subsubsection{Explanatory Variables}

Given word limitations, we present a list of explanatory variables included in analysis, rather than through an exhaustive explanation of each variable in texts. A detailed description of the independent variables is provided in Appendix A. For family background, we included (a) perceived family economic hardship, (b) parental education, (c) child's identification with parent, and (d) parental expectations for child's college education. For individual student characteristics, we included (a) gender, (b) race/ethnicity, (c) grade level (9th to 12th), (d) rural identity, (e) positive perception of economic opportunity at home communities, and (f) residential aspirations (home state vs. other state vs. don't know). For the school-level variable, we considered (a) college proximity, (b) percent of students receiving free/reduced lunch, (c) and rural locale (rural remote vs. rural fringe/distant). For school-experience variables, we included (a) curricular track (college prep vs. others), (b) achievement, (c) postsecondary preparation, (d) academic self-concept, and (e) school valuing.

\subsection{Analytic Strategies}

We implemented two major analytic strategies. First, we conducted multinomial logistic regression to identify factors associated with students' level of educational and occupational aspirations, respectively. Second, we performed multinomial logistic regression to identify factors associated with students' level of educational and occupational alignment. Multinomial logistic regression is appropriate when the dependent variable is 
categorical. In addition, this analytic approach provides greater flexibility when using both categorical (particularly dichotomous variables) and continuous predictor variables (Tabachnick \& Fidell, 2007).

For the missing data for the explanatory variables with exceptions for gender and race/ethnicity (see Appendix A), we employed a multiple imputation technique with the ice option in the Stata software package (Royston, 2004). We generated five data sets with five different sets of imputed values, and averaged the coefficients and standard errors from analyses across the five data sets using the mim option in Stata. To address the nested nature of the current data (i.e., students within sampled schools), we used the cluster option in Stata, which generates robust standard errors by downwardly adjusting for the inflated standard errors resulting from the violation of the independent errors assumption (Rogers, 1993).

\section{Results}

\subsection{Descriptive Findings}

The first set of analyses examined educational aspirations, occupational aspirations, and the alignment between these two among rural youth. Table 1 provides information-educational aspirations (row), occupational aspirations (column), and ambition alignment based on a combination of students' educational and occupational aspirations. Of those students with educational and occupational alignment information, $38 \%$ wanted to complete a four-year degree, and $43 \%$ wanted to obtain an advanced degree. For occupational aspirations, $25 \%$ of the students aspired to occupations requiring a four-year college degree, whereas $30 \%$ aspired to occupations that require an advanced degree. Overall, 39\% of students have educational and occupational ambitions that are aligned; whereas $46 \%$ have over-aligned ambitions, and $14 \%$ have under-aligned. Thus, nearly half of this rural sample aspired to occupations that required education and training levels above their reported educational aspirations.

Table 1. Comparison of educational and occupational aspirations

Minimum level of education needed for occupational aspirations

\begin{tabular}{|c|c|c|c|c|c|}
\hline Educational aspirations & $\begin{array}{l}\text { High school } \\
\text { only }\end{array}$ & Some college & $\begin{array}{l}\text { Four-year } \\
\text { college }\end{array}$ & $\begin{array}{l}\text { Graduate/ } \\
\text { professional }\end{array}$ & Total (row) \\
\hline High school only & $100(2.1)^{\mathrm{a}}$ & $59(1.2)^{b}$ & $15(0.3)^{\mathrm{c}}$ & $(0.1)^{\mathrm{c}}$ & $\overline{(3.7)}$ \\
\hline Some college & $226(4.7)^{d}$ & $334(6.9)^{\mathrm{a}}$ & $104(2.1)^{b}$ & $(1.2)^{\mathrm{c}}$ & $720 \quad(14.9)$ \\
\hline Four-year college & $304(6.3)^{\mathrm{e}}$ & $626(12.9)^{\mathrm{d}}$ & $520(10.7)^{\mathrm{a}}$ & $(8.3)^{b}$ & $1,851 \quad(38.2)$ \\
\hline Graduate/professional & $141(2.9)^{\mathrm{e}}$ & $421(8.7)^{\mathrm{e}}$ & $553(11.4)^{\mathrm{d}}$ & $974 \quad(20.1)^{\mathrm{a}}$ & $2,089 \quad(43.2)$ \\
\hline Total (column) & $771(15.9)$ & $1,440 \quad(29.8)$ & 1,192 & (29.7) & $4,840(100.0)$ \\
\hline
\end{tabular}

Note. Percentages in parentheses. The following subscripts denote ambition alignment categories:

${ }^{\text {a }}$ Aligned ambitions $(\mathrm{n}=1,928[39.8 \%])$.

${ }^{\mathrm{b}}$ Slight underaligned ambitions $(\mathrm{n}=564[11.7 \%])$.

${ }^{\mathrm{c}}$ Underaligned ambitions $(\mathrm{n}=77[1.68 \%])$.

${ }^{\mathrm{d}}$ Slight overaligned ambitions $(\mathrm{n}=1,405[29.0 \%])$.

${ }^{\mathrm{e}}$ Overaligned ambitions $(\mathrm{n}=866[17.9 \%])$.

\subsection{Predictors of Educational and Occupational Aspirations}

\subsubsection{Educational Aspirations}

Table 2 provides odds ratios of multinomial logistic regression predicting educational aspirations. In this analysis, aspirations of high school served only as the reference group. The odds ratio greater than one indicates the variable is associated with an increased likelihood of postsecondary degree attainment, while a value less than one indicates a decreased likelihood. Results showed that a number of family, student, school, and schooling experience variables significantly predicted educational aspirations. As prior studies students who experienced greater family economic hardship, lower parental education attainment, and lower expectations for college were 
less likely to aspire to a four-year degree or a graduate/professional degree. Also, lower educational aspirations were reported by youth with greater identification with parents.

Table 2. Odds ratios from multinomial logistic regression on educational aspirations

\begin{tabular}{|c|c|c|c|c|c|c|}
\hline \multirow{3}{*}{$\begin{array}{l}\text { Explanatory variables } \\
\text { Family characteristics }\end{array}$} & \multicolumn{6}{|c|}{ Base category $=$ High school only } \\
\hline & \multicolumn{2}{|c|}{ Some college } & \multicolumn{2}{|c|}{$\begin{array}{l}\text { Four-year } \\
\text { college }\end{array}$} & \multicolumn{2}{|c|}{$\begin{array}{c}\text { Graduate/ } \\
\text { professional }\end{array}$} \\
\hline & & & & & & \\
\hline Family economic hardship & 0.850 & & 0.758 & * & 0.736 & $* *$ \\
\hline Parents' level of Education & 1.012 & & 1.048 & & 1.120 & $*$ \\
\hline Parent respect and identification & 0.854 & $*$ & 0.820 & * & 0.822 & $*$ \\
\hline Parent expectation for college & 1.600 & $* * *$ & 2.249 & $* * *$ & 2.610 & $* * *$ \\
\hline \multicolumn{7}{|l|}{ Student characteristics } \\
\hline Female & 1.570 & $*$ & 2.360 & $* *$ & 3.159 & $* * *$ \\
\hline \multicolumn{7}{|l|}{ Race/ethnicity (omitted) } \\
\hline African American & 0.796 & & 0.707 & & 0.862 & \\
\hline Hispanic/Latino & 0.522 & & 0.781 & & 0.764 & \\
\hline Native American & 0.794 & & 0.776 & & 0.719 & \\
\hline Multiracial & 1.171 & & 1.457 & & 1.958 & $*$ \\
\hline Grade level & 1.143 & & 0.840 & & 0.775 & $* *$ \\
\hline Rural identity & 0.935 & & 0.947 & & 0.845 & $*$ \\
\hline Positive perceptions of local job opportunity & 0.870 & & 0.729 & $* *$ & 0.672 & $* * *$ \\
\hline \multicolumn{7}{|l|}{ Residential aspirations (home state omitted) } \\
\hline Another state & 1.030 & & 1.503 & & 2.207 & $* *$ \\
\hline Have not thought or decided & 1.458 & & 2.126 & $* *$ & 2.698 & $* * *$ \\
\hline \multicolumn{7}{|l|}{ School characteristics } \\
\hline College proximity & 1.001 & & 1.001 & & 0.998 & \\
\hline Percent free/reduced lunch & 0.498 & & 0.372 & & 0.494 & \\
\hline Rural remote & 0.748 & & 0.623 & $* *$ & 0.539 & $* *$ \\
\hline \multicolumn{7}{|l|}{ Schooling experiences } \\
\hline College prep program & 2.188 & & 4.387 & $* *$ & 6.501 & $* * *$ \\
\hline Achievement & 1.053 & & 1.257 & $* *$ & 1.592 & $* * *$ \\
\hline Postsecondary preparation & 2.165 & $* *$ & 2.677 & $* * *$ & 3.399 & $* * *$ \\
\hline Academic self-concept & 1.040 & & 1.217 & $*$ & 1.612 & $* * *$ \\
\hline School valuing & 1.535 & $* * *$ & 1.866 & $* * *$ & 2.369 & $* * *$ \\
\hline Log likelihood & \multicolumn{6}{|c|}{-4410.7381} \\
\hline Pseudo (McFadden's) $R$ & \multicolumn{6}{|c|}{0.198} \\
\hline $\mathrm{N}$ & \multicolumn{6}{|c|}{4,840} \\
\hline
\end{tabular}

Regarding student demographic characteristics, several interesting findings emerged. First, girls were more likely than boys to aspire to postsecondary education. Also, students who self-reported as multiracial or who 
planned to leave their home state were more likely to aspire to a graduate/professional degree. In contrast, students in the upper grades and students with higher levels of rural identity were less likely to aspire to graduate/professional training. Similarly, an inverse relation emerged between perceptions of local economic opportunities and educational aspirations.

Several school-related predictors were significant. First, students attending schools in rural remote locations were less likely than their counterparts in rural fringe/distant schools to aspire to college or graduate/professional school. Second, students who took part in postsecondary preparation activities and had higher levels of school valuing were more likely to aspire to some college education. In addition, students enrolled in a college preparation programs, took part in postsecondary preparation activities, and had higher levels of achievement, academic self-concept, and school valuing were more likely to aspire to higher levels of postsecondary educational attainment. In sum, results suggested that students' schooling experiences were important influences on educational aspirations beyond family and individual characteristics.

\subsubsection{Occupational Aspirations}

Table 3 provides odds ratios of multinomial logistic regression predicting the college and training levels associated with youth's occupational aspirations. In general, the findings for family, individual and school influences on the educational levels of occupational aspirations mirrored those reported for levels of educational aspirations. As before, with individual and family influences controlled, schooling experiences were important predictors of the educational levels of occupational aspirations. Enrollment in college preparatory programs, teacher-reported grades, and self-reported academic self-concept were positive predictors of rural students' aspirations to jobs requiring college or a graduate/professional degree. In addition, students who participated in postsecondary preparation activities or who valued school reported occupations requiring higher levels of education and training.

Table 3. Odds ratios from multinomial logistic regression on occupational aspirations

\begin{tabular}{|c|c|c|c|c|c|c|}
\hline \multirow{2}{*}{$\begin{array}{l}\text { Predictor variables } \\
\text { Family characteristics }\end{array}$} & \multicolumn{6}{|c|}{ Base category $=$ High school only } \\
\hline & \multicolumn{2}{|c|}{ Some college } & \multicolumn{2}{|c|}{$\begin{array}{l}\text { Four-year } \\
\text { college }\end{array}$} & \multicolumn{2}{|c|}{$\begin{array}{c}\text { Graduate/ } \\
\text { professional }\end{array}$} \\
\hline Family economic hardship & 0.913 & & 0.930 & & 0.871 & $* *$ \\
\hline Parents' level of education & 0.997 & & 1.054 & $* *$ & 1.031 & \\
\hline Parent respect and identification & 1.076 & & 0.969 & & 0.965 & \\
\hline Parent expectation for college & 1.120 & $* * *$ & 1.209 & $* * *$ & 1.315 & $* * *$ \\
\hline \multicolumn{7}{|l|}{ Student characteristics } \\
\hline Female & 5.944 & $* * *$ & 3.183 & $* * *$ & 4.588 & $* * *$ \\
\hline \multicolumn{7}{|l|}{ Race/ethnicity (White omitted) } \\
\hline African American & 1.175 & & 0.719 & $*$ & 1.074 & \\
\hline Hispanic/Latino & 1.657 & $*$ & 1.348 & & 1.712 & $*$ \\
\hline Native American & 1.251 & & 0.684 & & 1.038 & \\
\hline Multiracial & 0.837 & & 1.010 & & 1.092 & \\
\hline Grade level & 1.240 & $* * *$ & 1.280 & $* * *$ & 0.995 & \\
\hline Rural identity & 1.000 & & 0.987 & & 0.981 & \\
\hline Positive perceptions of local job opportunity & 0.949 & & 0.880 & $*$ & 0.871 & $* *$ \\
\hline \multicolumn{7}{|l|}{ Residential aspirations (home state omitted) } \\
\hline Another state & 0.879 & & 0.967 & & 1.036 & \\
\hline Have not thought or decided & 0.858 & & 0.920 & & 1.117 & \\
\hline School characteristics & & & & & & \\
\hline
\end{tabular}




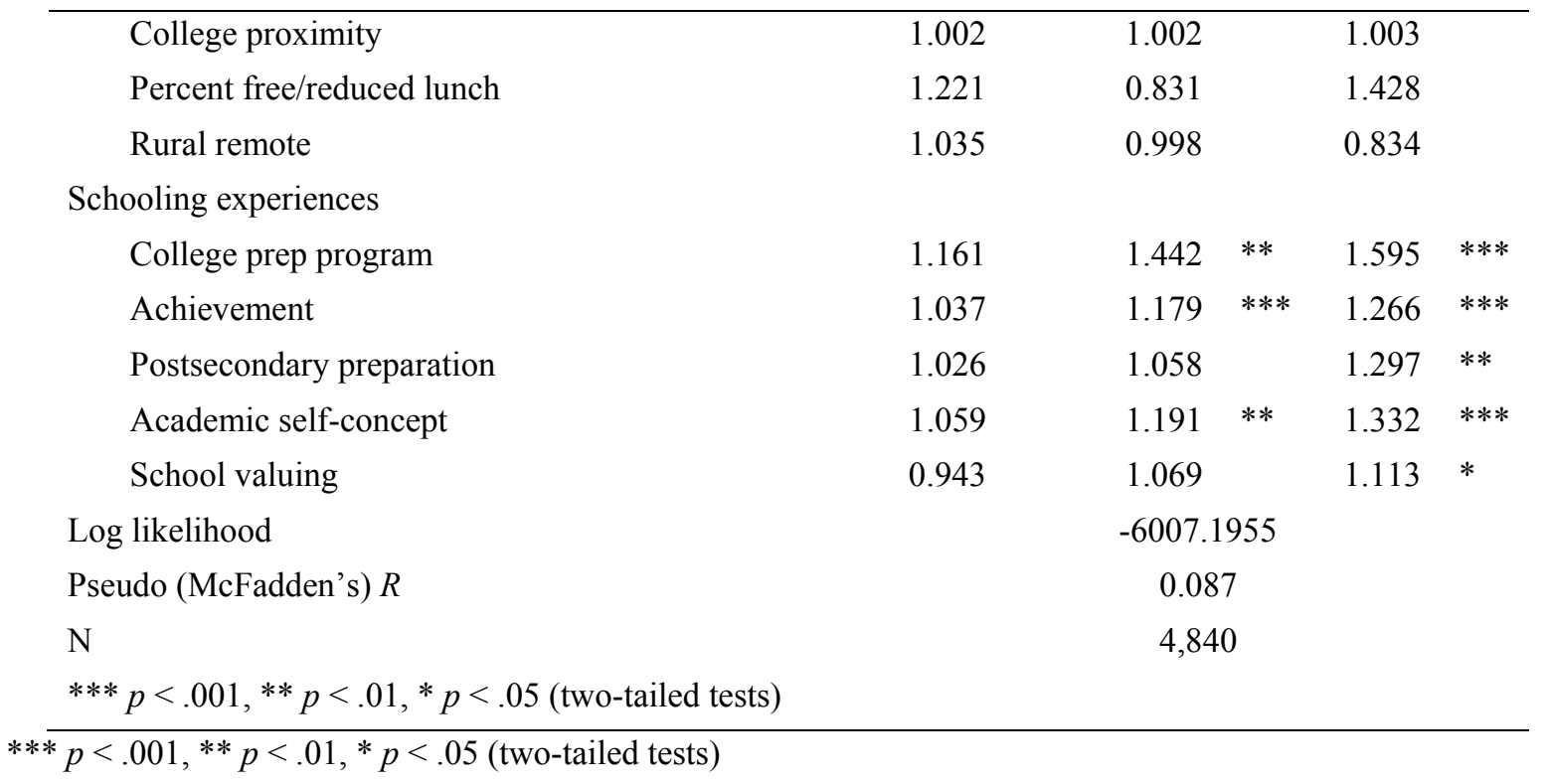

\subsubsection{Predictors of Misaligned Ambitions}

Table 4 provides odds ratios of multinomial logistic regression predicting misaligned ambitions. Regarding family characteristics, results showed that students who experienced greater family economic hardship and had greater parental respect and identification were more likely to have under-aligned ambitions. That is, the aspired to higher levels of education than needed for their occupational aspirations. In contrast, students whose parents had higher expectations for college were more likely to have over-aligned ambitions.

Regarding student characteristics, results showed that girls were less likely to have over-aligned ambitions than boys, whereas African American students were more likely to have over-aligned ambitions compared to white students. Older students were less likely than younger students to have over-aligned ambitions. Students who had positive perceptions of local job opportunities were more likely to have under-aligned ambitions. Finally, students who planned to move from their home state were less likely to have over-aligned ambitions.

Regarding school characteristics, results showed that students who attended schools closer to a college or university were less likely to have over-aligned ambitions. Also, students who attended schools with a higher proportion of the student body receiving free/reduced lunch were less likely to have over-aligned ambitions. Additionally, students with higher levels of achievement, school valuing and participation in postsecondary preparation activities were less likely to have under-aligned ambitions. Also, students enrolled in a college preparatory program were less likely to have slightly under-aligned ambitions. In sum, results suggested that schooling experiences helped to promote the aligned ambitions beyond family and individual background characteristics.

Table 4. Odds ratios from multinomial logistic regression on misaligned vs. aligned ambition status

\begin{tabular}{llccc}
\hline & \multicolumn{4}{c}{ Base category = Aligned ambitions } \\
Predictor variables & $\begin{array}{c}\text { Underaligned } \\
\text { ambitions }\end{array}$ & $\begin{array}{c}\text { Slightly } \\
\text { underaligned } \\
\text { ambitions }\end{array}$ & $\begin{array}{c}\text { Slightly } \\
\text { overaligned } \\
\text { ambitions }\end{array}$ & $\begin{array}{c}\text { Overaligned } \\
\text { ambitions }\end{array}$ \\
\hline Family characteristics & $1.453^{* *}$ & 1.007 & 1.036 & 1.055 \\
$\quad$ Family economic hardship & 1.001 & 0.972 & 1.006 & 1.002 \\
$\quad$ Parents' level of education & $1.263^{*}$ & 0.961 & 1.032 & 1.031 \\
$\quad$ Parent respect and identification & $0.760^{* * *}$ & 0.939 & 1.027 & $1.080^{* *}$ \\
Parent expectation for college & & & & \\
\hline Student characteristics & & & &
\end{tabular}




\begin{tabular}{|c|c|c|c|c|}
\hline Female & 1.577 & 1.037 & 1.044 & $0.808^{*}$ \\
\hline \multicolumn{5}{|l|}{ Race/ethnicity (White omitted) } \\
\hline African American & 2.202 & 1.148 & 0.944 & $1.381 * *$ \\
\hline Hispanic/Latino & 1.595 & 1.411 & 1.121 & 1.047 \\
\hline Native American & 2.213 & 1.027 & 1.059 & 1.183 \\
\hline Multiracial & 1.300 & 1.064 & 1.111 & 1.138 \\
\hline Grade level & 1.221 & 0.922 & $1.078 *$ & $0.837 * * *$ \\
\hline Rural identity & 0.993 & 1.070 & 1.008 & 0.955 \\
\hline Positive perceptions of local job opportunity & $1.239 *$ & $1.104 *$ & 1.061 & 1.031 \\
\hline \multicolumn{5}{|l|}{ Residential aspirations (home state omitted) } \\
\hline Another state & 0.906 & $0.738 *$ & 0.892 & $1.273 *$ \\
\hline Have not thought or decided & 0.994 & $0.728 *$ & $0.821 *$ & 1.160 \\
\hline \multicolumn{5}{|l|}{ chool characteristics } \\
\hline College proximity & 0.998 & 1.000 & $0.996 * *$ & 0.998 \\
\hline Percent free/reduced lunch & 2.492 & 1.036 & $0.628 * *$ & 1.071 \\
\hline Rural remote & 1.128 & 0.946 & 1.122 & 0.938 \\
\hline \multicolumn{5}{|l|}{ chooling experiences } \\
\hline College prep program & 0.418 & $0.755 *$ & 0.972 & 0.914 \\
\hline Achievement & $0.802 *$ & $0.906 * *$ & 0.961 & $0.938 *$ \\
\hline Postsecondary preparation & $0.627 * *$ & $0.830 *$ & $0.792 * * *$ & 1.072 \\
\hline Academic self-concept & 0.900 & 1.023 & 0.945 & 0.990 \\
\hline School valuing & $0.763 *$ & $0.896^{*}$ & 1.032 & 1.073 \\
\hline og likelihood & \multicolumn{4}{|c|}{-6361.9835} \\
\hline \multirow[t]{2}{*}{ seudo (McFadden's) $R$} & \multicolumn{4}{|c|}{0.026} \\
\hline & \multicolumn{4}{|c|}{4,840} \\
\hline
\end{tabular}

\section{Discussion}

Youth's aspirations, expectations, and plans serve as important guideposts to the future (Bandura et al. 2001; Schneider \& Stevenson 1999). Results of this study provide one of the first portraits of U.S. rural youth transitioning into adulthood in the early 21 st century. Compared to rural youth of the 1980s and 1990s (e.g., Cobb et al. 1989; Haller \& Virkler 1993; Rojewski, 1999), a majority of the participants (51\%) aspired to attend or to complete their studies at a two- or four-year postsecondary institution. Additionally, a majority of the participating youth aspired to adulthood jobs and careers that required a college education $(38 \%)$ or a postgraduate degree (18\%). Nearly half of the 4840 rural high school students aspired to careers in healthcare, education, or technical fields. Overall, the findings of this study are consistent with national trends in adolescents' educational and vocational aspirations plans. America's youth today have higher educational goals and aspirations than previous generations (Ingels \& Dalton 2008; Schneider \& Stevenson1999; Synder \& Dillow 2010).

An important goal of the current study was to examine the alignment of youth's educational and vocational aspirations. To our knowledge, this issue has not been addressed in prior research on rural youth. The results showed that approximately $40 \%$ of the participants had aligned educational and occupational aspirations. Another $46 \%$ had over-aligned aspiration because they overestimated the level of education needed to meet their career goals, and $24 \%$ had under-aligned aspirations. These numbers are roughly equivalent to those reported by Schneider and Stevenson (1999) for sample of urban and rural youth in the United States. 
Another goal was to examine variations in patterns of alignment related to family, individual, and school factors. The results provide several interesting explanations for relations between youth's educational and vocational aspirations. Two family characteristics were related to misalignment. First, consistent with prior research, youth's aspirations were significantly related to family income (Demi et al., 2010; Smith et al. 1995; Roscigno \& Crowley 2001; Roscigno et al. 2006). Perceptions of limited family income decreased youth's aspirations for a four-year college degree and for a job requiring postsecondary education. These results indicate that family income continues to constrain the future prospects of rural youth. The story of socioeconomic constraints is not unique to rural populations (McLoyd 1998; Entwisle, Alexander, \& Olsen, 2010). However, a disproportionately greater number of rural than urban youth reside in impoverished communities (Johnson \& Strange 2009). Rural poverty also is disproportionately focused on nonwhite ethnic minorities, and it tends to be intergenerational and long lasting (Lichter \& Johnson 2007). To counteract these patterns, low-income youth need access to information and job experiences that enable them to fulfill their occupational aspirations.

Consistent with prior research (Demi et al., 2010; Smith et al., 1995), the results also highlight the important role of youth's perceptions of their parent's educational expectations. Looking at youth's plans to obtain some college education or to enter occupations requiring some college, higher parental educational expectations increased the likelihood that youth plan to continue their education beyond high school and to enter a career requiring some postsecondary education by 60 percent and 125 percent, respectively. Within rural communities, these vocational choices generally include trade, healthcare, and service occupations which are critical for maintaining rural communities. On the other hand, youth's perceptions of parental educational expectations increased the likelihood they would overestimate the level of education needed to meet their occupational aspirations. Although Schneider and Stevenson (1999) reported a similar result, this misalignment for rural samples may be due to the youth's desire to fulfill parental and family expectations, while aspiring to occupations available in the local community as a way to remain close to family and maintain their rural identity. These occupations may or may not require a college or professional degree.

Along with family characteristics, several individual attributes also were predictive of youth's educational and vocational aspirations. First, consistent with prior research (Schneider \& Stevenson, 1999), grade level was an important predictor of aspirations and misalignment. As youth enter adolescence, they are still forming a sense of future identity. With time, these future orientations become more realistic as youth gain access to information about postsecondary education and careers (Lapan, Tucker, Kim, \& Kosciulek, 2003). Also, female participants aspired to higher postsecondary education and to enter careers requiring higher education than did their male counterparts (Chenoweth \& Galliher, 2004; Elder \& Conger, 2000). Rural girls also were 19\% less likely than boys to have over-aligned aspirations in this study.

New to research on rural youth are the differences in educational and vocational aspirations related to ethnicity. Without prior research to ground these findings, it is premature to draw conclusions. Nonetheless, African American and Latino youth in U.S. rural communities reported higher educational aspirations than their white peers. It may be, like girls in these rural communities, minority youth see few employment options available to them that would enable them to obtain a modest but comfortable lifestyle. Among the ethnic groups examined in this study, African American were 38\% more likely to aspire to education levels over what is needed for their desired occupations. As before, this finding needs to be interpreted within a rural context. The educational aspirations of African Americans have been rising steadily rising for decades (Jacob \& Wilder, 2009). Yet the employment opportunities for well-educated African Americans are limited in rural communities with the United States (Gibbs 2005; Gibbs, Kusmin, \& Cromartie, 2005).

Two other key individual characteristics predicted youth's educational and occupational aspirations in this study. In general, the findings indicated that rural youth with more positive perceptions of local job opportunities and with residential aspirations to remain in their home communities have lower educational aspirations. Additionally, those students with more positive perceptions of local career opportunities had lower aspirations for jobs that required postsecondary education. Such findings are consistent with prior research indicating that rural youth must lower their aspirations if they plan to remain in their communities (Corbett, 2007; Elder et al., 1996; Hektner, 1995). Regarding patterns of alignment, however, the findings indicated that youth who aspire to remain in their rural community underestimated the level of education needed to meet their occupational aspirations. The same was true for rural youth with positive perceptions of local job opportunities. Taken together, these findings have important implications for educators and parents. As rural communities undergo significant social and economic changes, rural youth who desire to remain in those communities may lack the information needed to choose the educational pathway needed to obtain their occupational goal. 
The study also examined the role of school characteristics and schooling experiences on youth's aspirations. The results contributed several important findings. First, with family and individual background controlled, school-related factors were significant predictors of rural adolescents' educational and vocational aspirations. As prior research had suggested (Howley, 2006), youth attending schools in remote rural locations had lower aspirations for a graduate or professional degree when compared to youth from other locations. All the school experiences (e.g., enrollment in college preparation programs, academic achievement, etc.) positively predicted educational aspirations as well as occupational aspirations requiring higher levels of education. In addition, youth who participated in postsecondary preparation activities and college preparation programs had more aligned educational and vocational aspirations. Similarly, youth who reported higher levels of academic achievement and valuing of school were less likely to have misaligned aspirations.

The study has several limitations that need to be addressed in future research on rural youth. First the design of the study was cross-sectional and only involved a single point in time. Consequently, directionality and causality cannot be inferred from the data. Given the large sample size, the study also relied on survey methods. Strong relations among constructs measured by self-reports may be due to shared method variance. Last, rural communities in the United States are very diverse. Although the study included a large sample of youth from across the United States, the findings do not apply to all rural communities within and outside the United States.

\section{Conclusions}

The present study has several important practical and theoretical implications. Aspirations are a malleable educational outcome influenced by many school-related experiences, including school achievement (Bandura et al., 2001), curricular tracking (Mau \& Bikos, 2000), school climate (Majoribanks, 2004), and access to vocational development programs (Gray 2009; Lee \& Ekstom, 1987). Consistent with other national studies (Ingels \& Dalton, 2008; Synder \& Dillow, 2010), growing numbers of rural youth aspire to continue their education into the postsecondary years. Yet little research has examined the college- or career- readiness of rural youth. Research is needed to examine the types of high school preparatory activities that enable rural youth to make successful transitions to postsecondary education, work and community life.

A small but growing body of literature is beginning to identify important factors within rural schools that make a difference in rural youth's academic achievement, school engagement, and early adult success (Applegate, 2008; Farmer et al., 2006; Gibbs et al. 2005; Howley 2006; Haas \& Nachtigal 1998). This research emphasizes that strong community-school relations are critical for providing a quality education in rural schools. Successful rural schools are able to provide youth not only with a pathway toward the future but also with ways to remain connected to their communities (Farmer et al., 2006; Gibbs et al., 2005; Howley, 2006; Schaftt, 2010). For rural youth, this place-based focus engenders a sense of connection and responsibility, which is vital to the sustainability and welfare of rural communities.

\section{Acknowledgements}

This work was supported by grant \#R305A04056 from the Institute of Education Sciences, U.S. Department of Education, Washington, D.C., USA. The views expressed in this article are ours and do not represent the granting agency.

\section{References}

Adelman, C. (2006). The toolbox revisited: Paths to degree completion from high school through college. Washington, D.C.: U.S. Department of Education. Retrieved from http://www.ed.gov/rschstat/research/pubs/toolboxrevisit/index.html

Applegate, P. (2008, April). The qualities that differential high-achieving and low-achieving high-poverty rural high schools: A transformative mixed methods study. Paper presented at the annual meeting of the American Educational Research Association. New York, New York.

Arnold, M. L., Biscoe, B., Farmer, T. W., Robertson, D. L., \& Shapley, K. L. (2007). How the government defines rural has implications for education policies and practices (Issues \& Answers Report, REL 2007-No. 010). Washington, DC: U.S. Department of Education, Institute of Education Sciences, National Center for Education Evaluation and Regional Assistance, Regional Educational Laboratory Southwest.

Arnold, M. L., Newman, J. H., Gaddy, B. B., \& Dean, C. B. (2005). A look at the condition of rural education research. Setting a direction for future research. Journal of Research in Rural Education, 20(6). Retrieved from http://jrre.psu.edu/articles/20-6.pdf 
Bandura, A., Barbaranelli, C., Caprara, G. V., \& Pastorelli, C. (2001). Self-efficacy beliefs as shapers of children's aspirations and career trajectories. Child Development, 72(1), 187-206. http://dx.doi.org/10.1111/1467-8624.00273

Beal, S. J., \& Crockett, L. (2010). Adolescents' occupational and educational aspirations and expectations: Links to high school activities and adult educational attainment. Developmental Psychology, 46, 258-265. http://dx.doi.org/10.1037/a0017416

Bronfenbrenner, U., \& Evans, G. W. (2000). Developmental science in the 21st century: Emerging questions, theoretical models, research designs, and empirical findings. Social Development, 9, 115-125. http://dx.doi.org/doi:10.1111/1467-9507.00114

Brown, D. L., \& Schafft, K. A. (2011). Rural People and Communities in the 21st Century. Cambridge, MA: Polity Press.

Bozick, R. (2007). Making it through the first year of college: The role of students' economic resources, employment, and living arrangements. Sociology of Education, 80, 361-385. http://dx.doi.org/10.1177/003804070708000304

Cairns, R. B. (2000). Developmental science: Three audacious implications. In L. R. Berman, R. B. Cairns, L. Nilsson, \& L. Nystedt (Eds.), Developmental science and the holistic approach (pp. 49-62). Mahwah, NJ: Lawrence Erlbaum Associates.

Cairns, R. B., Elder, G. H., \& Costello, E. J. (Eds.). (1996). Developmental science. New York: Cambridge University Press. http://dx.doi.org/10.1017/CBO9780511571114.001

Carr, P., \& Kefalas, M. J. (2009). Hollowing out the middle: The rural brain drain and what it means for America. Boston, MA: Beacon Press.

Chenoweth, E., \& Galliher, R. V. (2004). Factors influencing college aspirations of rural West Virginia high school students. Journal of Research in Rural Education, 19(2), 1-14. Retrieved from http://www.jrre.psu.edu/articles/19-2.pdf

Cobb, R. A., McIntire, W. G., \& Pratt, P. A. (1989). Vocational and educational aspirations of high school students: A problem for rural America. Research in Rural Education, 6, 11-15. Retrieved from http://www.jrre.psu.edu/articles/v6,n2,p11-16,Cobb.pdf

Coleman, J. S. (1988). Social capital in the creation of human capital. American Journal of Sociology, 94, 95-120. http://dx.doi.org/10.1086/228943

Corbett, M. (2007). Learning to leave. The irony of schooling in a coastal community. Black Point, Nova Scotia: Fernwood Publishing.

Crockett, L. J., Shanahan, M. J., \& Jackson-Newsom, J. (2000). Rural youth: Ecological and life course perspectives. In. R. Montemayor (Ed.), Advances in adolescent development: Vol. 9. Adolescent experiences: Cultural and economic diversity in adolescent development. Thousand Oaks, CA: Sage.

Demi, M., Coleman-Jensen, A., \& Snyder, A. (2010). The rural context and post-secondary school enrollment: An ecological systems approach. Journal of Research in Rural Education, 25(7). Retrieved from http://www.jrre.psu.edu/articles/25-7.pdf

DeYoung, A. J., Howley, C., \& Theobald, P. (1995). The cultural contradictions of middle schooling for rural community survival. Journal of Research in Rural Education, 11, 24-35. Retrieved from http://www.jrre.psu.edu/articles/v11,n1,p24-35,DeYoung.pdf

Duncan, C. M. (2001). Social capital in America's poor rural communities. In S. Saegert, J. P. Thompson, \& M. R. Warren (Eds.), Social capital and poor communities (pp. 60-86). New York, NY: Russell Sage Foundation.

Eccles, J., Brown, B. V., \& Templeton, J. (2008). A developmental framework for selecting indicators of well-being during the adolescent and young adult years. In B. V. Brown (Ed.), Key indicators of child and youth well-being (pp. 197-236). New York, NY: Lawrence Erlbaum Associates.

Eccles, J. S., Vida, M. N., \& Barber, B. (2004). The relation of early adolescents' college plans and both academic ability and task-value beliefs to subsequent college enrollment. Journal of Early Adolescence, 24, 63-77. http://dx.doi.org/10.1177/0272431603260919 
Elder, G. H., \& Conger, R. D. (2000). Children of the land: Adversity and success in rural America. Chicago: University of Chicago Press.

Elder, G. H., King, V., \& Conger, R. D. (1996). Attachment to place and migration prospects: A Developmental Perspective. Journal of Research on Adolescence, 6(4), 397-425. Retrieved from http://www.eric.ed.gov/ERICWebPortal/detail?accno=EJ534641

Entwisle, D., Alexander, K., \& Olsen, L. (2010). Socioeconomic status. Its broad sweep and long reach in education. In J. L. Meece, \& J. S. Eccles (Eds.), Handbook of research on schools, schooling, and human development (pp. 237-255). New York, NY: Routledge, Taylor, Francis, and Group.

Estell, D. B., Farmer, T. W., Cairns, R. B., \& Cairns, B. D. (2002). Social relations and academic achievement in inner-city early elementary classrooms. International Journal of Behavioral Development, 26, 518-528. http://dx.doi.org/10.1080/01650250143000472

Farmer, T. W. (2006, June). The role of rural education in the future of rural communities and the people who live in them. Paper presented at the Research and Policy Workshop of the Economic Research Service of the U.S. Department of Agriculture. Washington, D. C.

Farmer, T. W., Dadisman, D., Latendresse, S. J., Thompson, J., Irvin, M. J., \& Zhang, L. (2006). Educating out and giving back: Adults' conceptions of successful outcomes of African American high school students from impoverished rural communities. Journal of Research in Rural Education, 21(10), 1-12. Retrieved from http://www.jrre.psu.edu/articles/21-10.pdf

Findeis, J., \& Jensen, L. (1998). Employment opportunities in rural areas: Implications for poverty in a changing policy environment. American Journal of Agricultural Economics, 80, 1000-1007. http://dx.doi.org/10.2307/1244194

Flora, C. B., Flora, J. L., \& Fey, S. (2003). Rural communities. Legacy and change. Boulder, CO: Westview Press.

Gandara, P., Gutierrez, D., \& O'Hara, S. (2001). Planning for the future in rural and urban high schools. Journal of Education for Students Placed at Risk, 6, 73-93.

Gibbs, R. (2005). Education as a rural development strategy. Amber Waves, 3(5), 20-25. Retrieved from http://ezaccess.libraries.psu.edu/login?url=http://search.proquest.com.ezaccess.libraries.psu.edu/docview/20 4850066? accountid $=13158$

Gibbs, R., Kusmin, L., \& Cromartie, J. (2005). Low skill employment and the changing economy of rural America. USDA Economic Research Report No. 10. Washington, DC: United States Department of Agriculture.

Goyette, K. A. (2008). College for some to college for all: Social background, occupational expectations, and educational expectations over time. Social Science Research, 37, 461-484. http://dx.doi.org/10.1016/j.ssresearch.2008.02.002

Gray, K. (2009). Getting real: Helping teens find their future (2nd ed.). Thousand Oaks, CA: Corwin Press.

Haas, T., \& Nachtigal, P. (1998). Place value: An educator's guide to good literature on rural lifeways, environments, and purposes of education. Charleston, WV: ERIC Clearinghouse on Rural Education and Small Schools.

Haller, E. J., \& Virkler, S. J. (1993). Another look at rural- nonrural differences in students' educational aspirations. Journal of Research in Rural Education, 9(3), 170-178. Retrieved from http://www.jrre.psu.edu/articles/v9,n3,p170-178,Haller.pdf

Hardré, P. L., \& Hennessey, M. N. (2010). Two rural worlds: Differences of rural high school students' motivational profiles in Indiana and Colorado. Journal of Research in Rural Education, 25. Retrieved from http://www.jrre.psu.edu/articles/25-8.pdf

Hardré, P. L., Sullivan, D. W., \& Crowson, M. H. (2009). Student characteristics and motivation in rural high schools. Journal of Research in Rural Education, 24, 1-19. Retrieved from http://www.jrre.psu.edu/articles/24-16.pdf

Hektner, J. M. (1995). When moving up implies moving out: Rural adolescent conflict in the transition to adulthood. Journal of Research in Rural Education, 11(1), 13-14. Retrieved from http://www.jrre.psu.edu/articles/v11,n1,p3-14,Hektner.pdf 
Howley, C. B. (1997). How to make rural educational research "rural": An essay at practical advice. Journal of Research in Rural Education, 13, 131-138. Retrieved from http://www.jrre.psu.edu/articles/v13,n2,p131-138,Howley.pdf

Howley, C. B., Harmon, H., \& Leopold, G. (1996). Rural scholars or bright rednecks? Aspirations for a sense of place among rural youth in Appalachia. Journal of Research in Rural Education, 12, 150-160. Retrieved from http://www.jrre.psu.edu/articles/v12,n3,p150-160,Howley.pdf

Howley, C. W. (2006). Remote possibilities: Rural children's educational aspirations. Peabody Journal of Education, 81(2), 62-80. http://dx.doi.org/10.1207/S15327930pje8102_4

$\mathrm{Hu}, \mathrm{S}$. (2003). Educational aspirations and postsecondary access and choice: Students in urban, suburban, and rural schools compared. Educational Policy Analysis Archives, 11, 1-13. Retrieved from http://epaa.asu.edu/epaa/v11n14/

Ingels, S. J., \& Dalton, B. W. (2008). Trends among high school seniors, 1972-2004 (NCES 2008-320). Washington, DC: National Center for Education Statistics, Institute for Education Sciences, U.S. Department of Education. Retrieved from http://www.eric.ed.gov/ERICDocs/data/ericdocs2sq1/content_storage_01/0000019b/80/3e/00/08.pdf

Irvin, M. J., Farmer, T. W., Leung, M-C., Thompson, J. H., \& Hutchins, B. C. (2010). School, community, and church activities: Relationship to academic achievement of low-income African American early adolescents in the rural Deep South. Journal of Research in Rural Education, 25, 1-21. Retrieved from http://www.jrre.psu.edu/articles/25-4.pdf

Johnson, J., \& Strange, M. (2009). Why rural matters 2009: State and Regional Challenges and Opportunities. Arlington, VA: The Rural School and Community Trust.

Johnson, M., Elder, G. H., \& Stern, M. (2005). Attachments to family and community and the young adult transition to rural youth. Journal of Research on Adolescence, 15(1), 99-125. http://dx.doi.org/10.1111/j.1532-7795.2005.00088.x

Jones, M. H., \& Estell, D. B. (2010). When elementary students change peer groups: Intragroup centrality, intergroup centrality, and self-perceptions of popularity. Merrill-Palmer Quarterly -Journal of Developmental Psychology, 56, 164-188. Retrieved from http://search.proquest.com/docview/375023271?accountid=13158

Kannapel, P. J., \& DeYoung, A. J. (1999). The rural school problem in 1999: A review and critique of the literature. Journal of Research in Rural Education, 15, 67-79. Retrieved from http://www.jrre.psu.edu/articles/v15,n2,p67-79,Kannapel.pdf

Lapan, R., Tucker, B., Kim, S., \& Kosciulek. (2003). Preparing rural adolescents for post-high school transitions. $\begin{array}{lllll}\text { Journal of Counseling and } & \text { 329-342. }\end{array}$ http://dx.doi.org/10.1002/j.1556-6678.2003.tb00260.x

Lee, V. E., \& Ekstrom, R. B. (1987). Student access to guidance counseling in high school. American Educational Research Journal, 24(2), 287-310. http://dx.doi.org/10.3102/00028312024002287

Lent, R. W., Brown, S. D., \& Hackett, G. (1994). Toward a unifying social cognitive theory of career and academic interest, choice and performance. Journal of Vocational Behavior, 45(1), 79-122. http://dx.doi.org/10.1006/jvbe.1994.1027

Lichter, D. T., \& Johnson, K. M. (2007). The changing spatial concentration of America's rural poor population. Rural Sociology, 72(3), 331-358. http://dx.doi.org/10.1526/003601107781799290

Marijoribanks, K. (2003). Family background, individual and environmental influences, aspirations and young adults' educational attainment: A follow-up study. Educational Studies, 29, 233-242.

Mau, W., \& Bikos, L. H. (2000). Educational and vocational aspirations of minority and female students: A longitudinal study. Journal of Counseling and Development, 78, 186-194. http://dx.doi.org/10.1002/j.15566676.2000.tb02577.x

McLoyd, V. (1998). Socioeconomic disadvantage and child development. American Psychologist, 53, 185-201. http://dx.doi.org/10.1037//0003-066X.53.2.185

McNeal, R. B. Jr. (1999). Parental involvement as social capital: Differential effectiveness on science achievement, truancy, and dropping out. Social Forces, 78, 117-144. http://dx.doi.org/10.2307/3005792 
Petrin, R. A., Farmer, T. W., Meece, J. L., Byun, S., Brooks, D. S., \& Hall, C. M. (2011). Interpersonal competence configurations, attachment to community, and residential aspirations of rural adolescents. Journal of Youth and Adolescence, 40, 1091-1105. http://dx.doi.org/10.1007/s10964-011-9690-2

Provasnik, S., KewalRamani, A., Coleman, M. M., Gilbertson, L., Herring, W., \& Xie, Q. (2007). Status of education in rural America (NCES 2007-040). Washington, DC: National Center for Education Statistics, Institute of Education Sciences, U.S. Department of Education.

Rogers, W. H. (1993). Regression standard errors in clustered samples. Stata Technical Bulletin, 13, 19-23. Retrieved from http://ideas.repec.org/a/tsj/stbull/y1994v3i13sg17.html

Rojewski, J. W. (1999). Career-related predictors of work-bound and college-bound status of adolescents in rural and nonrural areas. Journal of Research in Rural Education, 15(3), 141-156. Retrieved from http://www.jrre.psu.edu/articles/v15,n3,p141-156,Rojewski.pdf

Roscigno, V. J., \& Crowley, M. L. (2001). Rurality, institutional disadvantage, and achievement/attainment. Rural Sociology, 66, 268-293. http://dx.doi.org/10.1111/j.1549-0831.2001.tb00067.x

Roscigno, V. J., Tomaskovic-Devey, D., \& Crowley, M. (2006). Education and the inequalities of place. Social Forces, 84(4), 2121-2145. http://dx.doi.org/10.1353/sof.2006.0108

Royston, P. (2004). Multiple imputation of missing values. Stata Journal, 4, 227-241. Retrieved from $\mathrm{http}: / / \mathrm{www}$. stata-journal.com/sjpdf.html?articlenum $=$ st0067

Sabates, R., Harris, A. L., \& Staff, J. (2011). Ambition gone awry: The long-term socioeconomic consequences of misaligned and uncertain ambitions in adolescence, 92, 959-977. http://dx.doi.org/10.1111/j.15406237.2011.00799.x

Schafft, K. A. (2010). Economics, community, and rural education: Rethinking the nature of accountability in the twenty-first century. In K. A. Schafft, \& A. Y. Jackson (Eds.), Rural education for the twenty-first century (pp. 275-289). University Park, PA: The Pennsylvania State University Press.

Schneider, B., \& Stevenson, D. (1999). The Ambitious Generation: America's teenagers, motivated but directionless. New Haven, CT and London, England: Yale University Press.

Smith, M. H., Beaulieu, L. J., \& Seraphine, A. (1995). Social capital, place of residence, and college attendance. Rural Sociology, 60, 363-380. http://dx.doi.org/10.1111/j.1549-0831.1995.tb00578.x

Snyder, T. D., \& Dillow, S. A. (2010). Digest of education statistics 2009 (NCES 2010-013). National Center for Education Statistics, Institute of Education Sciences, U.S. Department of Education. Washington, D. C.

Stevens, G., \& Cho, J. H. (1985). Socioeconomic indexes and the new 1980 census occupational classification scheme. Social Science Research, 14, 142-168. http://dx.doi.org/10.1016/0049-089X(85)90008-0

Tabachnick, B. G., \& Fidell, L. S. (2007). Using multivariate statistics (5th ed.). Boston: Pearson Education, Inc.

Turley, R. N. L. (2009). College proximity: Mapping access to opportunity. Sociology of Education, 82, 126-146. http://dx.doi.org/10.1177/003804070908200202

U.S. Department of Education. (2005). A profile of the American high school senior in 2004: A first look. Initial results from the first follow-up of the Education Longitudinal Study of Aspirations: A Logistic Transform Model. Washington, DC: National Center for Education Statistics, Institute of Education Sciences, U.S. Department of Education.

Zarrett, N., \& Eccles, J. (2006). The passage to adulthood: Challenges of late adolescence. In S. Piha, \& G. Hall (Eds.), New Directions for Youth Development (G. Noam, Editor-in-Chief), 111, 13-28. http://dx.doi.org/10.1002/yd.179

\section{Notes}

Note 1. Social capital is derived from social connections among family, schools, and community organizations. Close social ties within a community provide access to information and support beyond personal resources (Elder \& Conger 2000; Crockett et al. 2000).

Note 2. Information on federal Rural Educational Achievement Programs available at either ww2ed/programs/reaplisp or ww2ed/programs/reapsrsa. 
Note 3. We acknowledge the important contributions of those students who said "don't know," given that previous research finds that they are more likely to experience conflicting goals (Hektner, 1995). But this subject goes beyond the scope of this study and we hope to investigate this issue in other work. We have conducted supplementary analyses for those rural students who had valid information about their educational aspirations only $(\mathrm{N}=6,157)$ and found few differences in the predictors of educational aspirations. Results are available from first author upon request.

Note 4. We investigated reliability statistics and the structures of the latent variables (e.g., rural identity, academic self-concept, school valuing, etc.) using confirmatory factor analysis, and found that items for each construct functioned well to measure latent structures. Results are available from the first author on request.

Note 5. This question was asked only to those students who indicated that they did plan to work or have a career at age 30. Of 6,157 rural samples, 1,315 students (21 percent) indicated they did not plan to work or have a career at age 30 (or were unsure) so they did report their occupational aspirations. Supplementary analyses showed that compared to students who indicated they did plan to work at age 30, the students who indicated they did not plan to work at age 30, reported higher levels of family economic hardship, lower levels of educational expectations from parents, and less-favorable schooling experiences. The results of the supplementary analysis are available from the first author upon request.

Note 6. O*NET (http://www.onetonline.org/) is an online resource for occupational information developed by the U.S. Department of Labor/Employment and Training Administration. O*NET uses the Standard Occupational Classification (SOC) system to group jobs together based on similar duties, required skills, and levels of education. O*NET currently includes 965 occupations in 23 major occupational groups that represented the major occupational groupings used by many governmental agencies such as the U.S. Census Bureau, Department of Labor, and Department of Commerce (Stevens \& Cho 1985).

Appendix A. Description of the Explanatory Variables Included in Analyses $(\mathrm{N}=4,840)$

\begin{tabular}{|c|c|c|c|}
\hline Independent variables & Description & Mean (SE) & $\begin{array}{l}\% \\
\text { imputed }\end{array}$ \\
\hline
\end{tabular}

Family characteristics

Economic hardship

This variable was measured by averaging three items with

$\begin{array}{lll}1.77 & (0.01) & 4.17\end{array}$ five-point scales of never-all of the time to the following statements: (a) there is not enough money in my family to pay bills; (b) we don't have enough money in my family for things that are important; and (c) we don't have enough money to buy things my family needs or wants. Reliability statistics (i.e., Cronbach's alpha) were .879 . Factor loadings ranged from $.889(\mathrm{a}, \mathrm{c})$ to .920 (b).

Parental education

Student reported the highest level of their 13.61

$(0.04) \quad 8.53$ parents'education. The original given options: $1=\operatorname{did}$ not finish high school, 2 = graduated from high school or completed a GED, 3 = had some college education but did not complete a degree, $4=$ graduated from a two-year school, $5=$ graduated from a four-year college or university, $6=$ completed a master's degree, $7=$ completed Ph.D., M.D., or other advanced professional degree, $8=$ don't know. Higher one between mother's and father's educational attainment was chosen and transformed into years of schooling (e.g., $1=11,7=22$ ).

Parent respect and identification This variable was measured by averaging three items $\begin{array}{lll}4.37 & (0.02) & 1.28\end{array}$ with six-point scales of disagreement-agreement to the following statements: (a) when I grow up, I'd like to be like my parent/guardian; (b) I have a lot of respect for my parent/guardian; and (c) I really enjoy spending time with my parent/guardian. Reliability statistics were .764 . 
Factor loadings ranged from .717 to .898 .

Parental expectations for child's college education

\section{Student characteristics}

Female

Race/ethnicity

White

African American

Hispanic/Latino

Native American

Multiracial

Grade level

Rural identity

Positive perception of economic opportunity in home community

Residential aspirations

Home state

Another state

Have not thought or decided

\section{School characteristics}

College proximity

Percent free/reduced lunch
This variable was based on the two questions: how disappointed you think you mother or female guardian would be if you didn't graduate from college? and how disappointed you think you mother or female guardian would be if you didn't graduate from college?. Range of original responses for each question was from $1=$ not at all disappointed to $6=$ very disappointed. Original responses for each question were summed up and included as a continuous variable.

Student indicated their gender.

$0.55 \quad(0.01) \quad-$

Students indicated their racial or ethnic background. If students selected more than one race/ethnicity, they were classified as multiracial.

4.76

(0.02) 1.90

Students indicated their grade. $1=9$ th, $2=10$ th, $3=11$ th,
and $4=12$ th.
This variable was measured by averaging five items with
responses on six-point scales of not at all like me-a lot
like me to the statements: (a) I have a clear sense of my
rural background and what it means for me; (b) I am
happy that I live in a rural community; (c) I have a strong
sense of belonging to my own rural community; (d) I
have a lot of pride in my rural background; (e) I feel a
strong attachment to my rural background. Reliability
statistics were .914 . Factor loadings ranged from .745
to 913 .

This variable was measured by averaging three items with responses on six-point scales of disagreement-agreement: (a) it is easy to get a good-paying job around here; (b) a lot of people get benefits like health or vacation time for most jobs in this area; and (c) there are good jobs in the area for people like me. Reliability statistics were .672 . Factor loadings ranged from .782 to .803.

Students indicated where they wanted to live when they were 30 years old.

$0.08 \quad(0.00)$

$0.07 \quad(0.00)$

$0.04 \quad(0.00)$

$0.13 \quad(0.00)$

$2.44 \quad(0.02) \quad 0.06$

$2.98 \quad(0.02) \quad 5.41$

$2.90 \quad(0.02) \quad 9.19$

1.28

$0.38 \quad(0.01)$

$0.29 \quad(0.01)$

$0.32(0.01)$

Distance to closest college/university (miles). Information $42.24 \quad(0.44) \quad 1.07$ from 2004-2005 NCES Common Core of Data.

Percent of students in school who receive federally $0.50 \quad(0.00) \quad 0.00$ 
funded free or reduced lunch. Information from 2007-2008 NCE Common Core of Data.

Rural locale

\section{Schooling experiences}

College prep program

Achievement

Postsecondary preparation

Academic self-concept

School valuing

\section{Information from 2004-2005 NCES Common Core of} Data was used to classify schools based on geographic locale. Mean indicates proportion of students attending a rural remote school.

Student indicated a high school program in which they were enrolled. $1=$ college prep track, $0=$ else.

Students indicated their grades. $1=$ Mostly A's to $8=$ Below D's. The original scales were reversed $(1=$ below D's; 8 = Mostly A's).

This variable was measured by averaging four items with four-point scales of never-more than five times to the statements: (a) talked with a guidance counselor or other adviser about college; (b) visited a college campus; (c) searched for college courses or programs available by the internet; and (d) talked with your parents about how to pay for college; Reliability statistics were .656. Factor loadings ranged from .615 to .741 .

This variable was measured by averaging five items with seven-point scales of not at all good-very good to the following subjects: (a) English/ language arts; (b) mathematics; (c) science; (d) social studies; and (e) other classes. Reliability statistics were .731. Factor loadings ranged from .515 to .788 .

This variable was measured by averaging seven items with six-point scales of disagreement-agreement to the statements: (a) school is one of the most important things in my life; (b) most of what I learn in school will be useful when I get a job; (c) dropping out of school would be a huge mistake for me; (d) school is more important than most people think; (e) school is important to getting a good job; (f) the kind of education I'm getting here will help me later on; and $(\mathrm{g})$ what I study in school seems important to me; Reliability statistics were .851 . Factor loadings ranged from .529 to .815 .

\section{Copyrights}

Copyright for this article is retained by the author(s), with first publication rights granted to the journal.

This is an open-access article distributed under the terms and conditions of the Creative Commons Attribution license (http://creativecommons.org/licenses/by/3.0/). 